Article

\title{
Efficiency of Salicornia neei to Treat Aquaculture Effluent from a Hypersaline and Artificial Wetland
}

\author{
Mónica R. Diaz ${ }^{1}$, Javier Araneda ${ }^{1}$, Andrea Osses ${ }^{1}$, Jaime Orellana ${ }^{2}$ and José A. Gallardo ${ }^{1, *(1)}$ \\ 1 Escuela de Ciencias del Mar, Pontificia Universidad Católica de Valparaíso, 2340007 Valparaíso, Chile; \\ monica.diaz@pucv.cl (M.R.D.); javier.araneda.s@mail.pucv.cl (J.A.); andreaoss@gmail.com (A.O.) \\ 2 Erwin Sander Elektroapparatebau GmbH, 31311 Uetze-Eltze, Germany; jaime.orellana@aqua-sander.de \\ * Correspondence: jose.gallardo@pucv.cl; Tel.: +56-9-88542329
}

Received: 19 November 2020; Accepted: 9 December 2020; Published: 11 December 2020

\begin{abstract}
In this study, we evaluated the potential of Salicornia neei, a halophyte plant native to South America, to treat saline effluents with simulated concentration of ammonium-N (Amm) and nitrate-N (Nit) in a similar manner to land-based marine aquaculture effluents. Plants were cultivated for 74 days in drainage lysimeters under three treatments of seawater fertilized with: (1) Nit + Amm, (2) Nit, or (3) without fertilizer (Control). Over five repetitions, nitrogen removal efficiency (RE) was high in both treatments (Nit $+\mathrm{Amm}=89.6 \% \pm 1.0 \%$; Nit $88.8 \% \pm 0.9 \%$ ), whereas the nitrogen removal rate $(R R)$ was nonlinear and concentration-dependent $\left(R R_{\text {day1-4 }}\right.$ : Nit $+A m m=2.9 \pm 0.3 \mathrm{mg} \mathrm{L}^{-1} \mathrm{~d}^{-1}$, Nit $\left.=2.4 \pm 0.5 \mathrm{mg} \mathrm{L}^{-1} \mathrm{~d}^{-1} ; \mathrm{RR}_{\text {day5-8}}: \mathrm{Nit}+\mathrm{Amm}=0.8 \pm 0.2 \mathrm{mg} \mathrm{L}^{-1} \mathrm{~d}^{-1}, \mathrm{Nit}=1.0 \pm 0.2 \mathrm{mg} \mathrm{L}^{-1} \mathrm{~d}^{-1}\right)$. Effluent salinity increased from 40.6 to $49.4 \mathrm{~g} \mathrm{~L}^{-1}$ during the experiment, with no observed detrimental effects on RE or RR. High nitrogen removal efficiency and significant biomass production were observed $\left(\mathrm{Nit}+\mathrm{Amm}=11.3 \pm 2.0 \mathrm{~kg} \mathrm{~m}^{-2} ; \mathrm{Nit}=10.0 \pm 0.8 \mathrm{~kg} \mathrm{~m}^{-2} ;\right.$ Control $\left.=4.6 \pm 0.6 \mathrm{~kg} \mathrm{~m}^{-2}\right)$ demonstrate that artificial wetlands of $S$. neei can be used for wastewater treatment in saline aquaculture in South America.
\end{abstract}

Keywords: aquaculture effluents; halophyte; nitrogen accumulation; saline effluent; sustainable aquaculture

\section{Introduction}

Aquaculture provides nearly $50 \%$ of the world's fish production, and this is expected to increase to $60 \%$ by 2030 due to the growing demand for marine fishery products [1]. Land-based marine aquaculture systems will play an important role in meeting this demand and will also do so in a more environmentally sustainable way regarding marine aquaculture in the ocean [2,3]. However, the development of marine recirculating aquaculture systems (RASs) is limited by the ability to efficiently treat saline wastewater, which accumulates a large amount of nitrogen compounds derived from the metabolism of culture organisms [3-5]. In these RASs, the removal of nitrogen compounds, mainly ammonium $\left(\mathrm{NH}_{4}{ }^{+}\right)$ and ammonia $\left(\mathrm{NH}_{3}{ }^{-}\right)$, is a priority for elimination because they quickly degrade the water quality and have negative effects on the culture [6,7]. Biofilters that promote the conversion of ionized and deionized ammonium to nitrate $\left(\mathrm{NO}_{3}{ }^{-}\right)$are usually used for this purpose $[8,9] . \mathrm{NO}_{3}{ }^{-}$is not highly toxic to most cultured organisms $[10,11]$, with tolerable accumulated concentrations reported between 120 and $150 \mathrm{mg} \mathrm{L}^{-1}$ of $\mathrm{NO}_{3}{ }^{-}$in marine RASs [12].

The recent development of integrated systems allows for the use of RAS waste products as nutrients, coupling different water loops with the main fish production water system [13]. To take advantage of these waste products, such as nitrogen compounds that accumulate in marine RASs, the use of artificial wetlands with facultative or obligate halophytes has been proposed [14-16]. Halophyte plants have the ability to absorb different forms of $\mathrm{N}$, depending on different environmental factors, such as the 
availability of $\mathrm{CO}_{2}$ [17]. For example, some species of the genus Spartina show a higher affinity for $\mathrm{NH}_{4}{ }^{+}$ consumption $[18,19]$, whereas others such as Juncus maritimus have a marked preference for $\mathrm{NO}_{3}{ }^{-}$, even in substrates that have high availability of $\mathrm{NH}_{4}{ }^{+}$[20]. In addition, if the plants are grown in lysimeters or wetland, the interactions between the soil, microorganisms, and plants have a higher potential to remove nitrogen compounds and produce biomass, which can be used as animal feed or human food [21,22], and in the production of biofuels or by-products of interest to the pharmaceutical industry $[2,5,15,23,24]$, among other applications. Additionally, it has been demonstrated that these systems are also efficient in removing residual phosphates from RASs [2,15,23,25-27].

Salicornia neei is a succulent hydrohalophyte of herbaceous habit, native to South America and abundantly distributed on the South Pacific coast, where much of the marine aquaculture production in South America is concentrated [28]. S. neei is used as a gourmet food and is a type of emerging crop in the coastal zone of Chile. This plant has been described as containing high quantities of nutrients and important functional metabolites [22]. Additionally, physiological studies have been performed to observe germination patterns [29] and changes in the concentration of metabolites and antioxidants when exposed to different salinity gradients [30].

The objective of this study was to evaluate the capacity of the halophyte $S$. neei for use as a sink for dissolved nitrogen compounds in effluent from land-based marine aquaculture systems and to simultaneously evaluate the resulting biomass production. The data obtained in this study will allow us to establish whether $S$. neei is a plant suitable for treating land-based marine aquaculture effluent with the potential for use in marine recirculating aquaculture systems.

\section{Materials and Methods}

\subsection{Collection of Plant Material and Acclimatization}

In July 2014, 100 Salicornia neei plants with fully developed roots and shoots were collected in the "Salinas de Puyalli" wetland, located in the commune of Papudo, Valparaíso Region, Chile $\left(32^{\circ} 24^{\prime} 54^{\prime \prime}\right.$ S, $71^{\circ} 22^{\prime} 43^{\prime \prime} \mathrm{W}$ ) and subsequently transferred to the "Laboratorio Experimental de Acuicultura" of the Pontificia Universidad Católica de Valparaíso, in Valparaíso, Chile ( $33^{\circ} 1^{\prime} 21^{\prime \prime}$ S, $71^{\circ} 37^{\prime} 57^{\prime \prime}$ W). Plants were sown in sand beds and irrigated with Hoagland solution once per week for 10 weeks. Once the plants adapted and recovered their vigor, they were transferred to the experimental unit.

\subsection{Experimental Unit}

The experimental unit consisted of three RASs separated from each other, each composed of three drainage lysimeters (replicates). Each lysimeter was housed in a polyethylene container measuring $0.5 \times 0.6 \times 0.6 \mathrm{~m}$ (length $\times$ width $\times$ depth) with a surface area of $0.3 \mathrm{~m}^{2}$ and a total area per RAS of $0.9 \mathrm{~m}^{2}$. In each lysimeter, four $\mathrm{S}$. neei plants were planted until reaching a biomass of approximately $1 \mathrm{~kg}$ per lysimeter or $3 \mathrm{~kg} \mathrm{~m}^{-2}$. A leachate collection system was installed in each lysimeter, consisting of a perforated pipe at the bottom to collect the water, followed by a layer of gravel with a diameter of $0.5 \mathrm{~cm}$ and height of $15 \mathrm{~cm}$, and polyethylene mesh with $0.3 \mathrm{~mm}$ pore size to cover the gravel. For the substrate, coarse sand was used to provide a depth of $35 \mathrm{~cm}$ (Figure 1). Each RAS was connected to a nutrient storage, which in turn was fed by a main tank that contained filtered seawater. Each nutrient storage tank was equipped with an aeration pump to promote biological nitrification processes. The irrigation water supply (influent) was performed with a $0.5 \mathrm{HP}$ centrifugal pump (Humboldt, TPM60). Each RAS was supplied daily with $30 \mathrm{~L} \mathrm{~m}^{-2} \mathrm{~d}^{-1}$ of water using a drip irrigation system, programmed to run for $15 \mathrm{~min}$ at 09:00 and at 17:00 $\mathrm{h}$. This guaranteed that a large proportion of the irrigation water will penetrated and was able to be collected at the bottom of the lysimeter. Drainage water (effluent) was returned to the respective collection tanks of each system to close the recirculating water loop. 


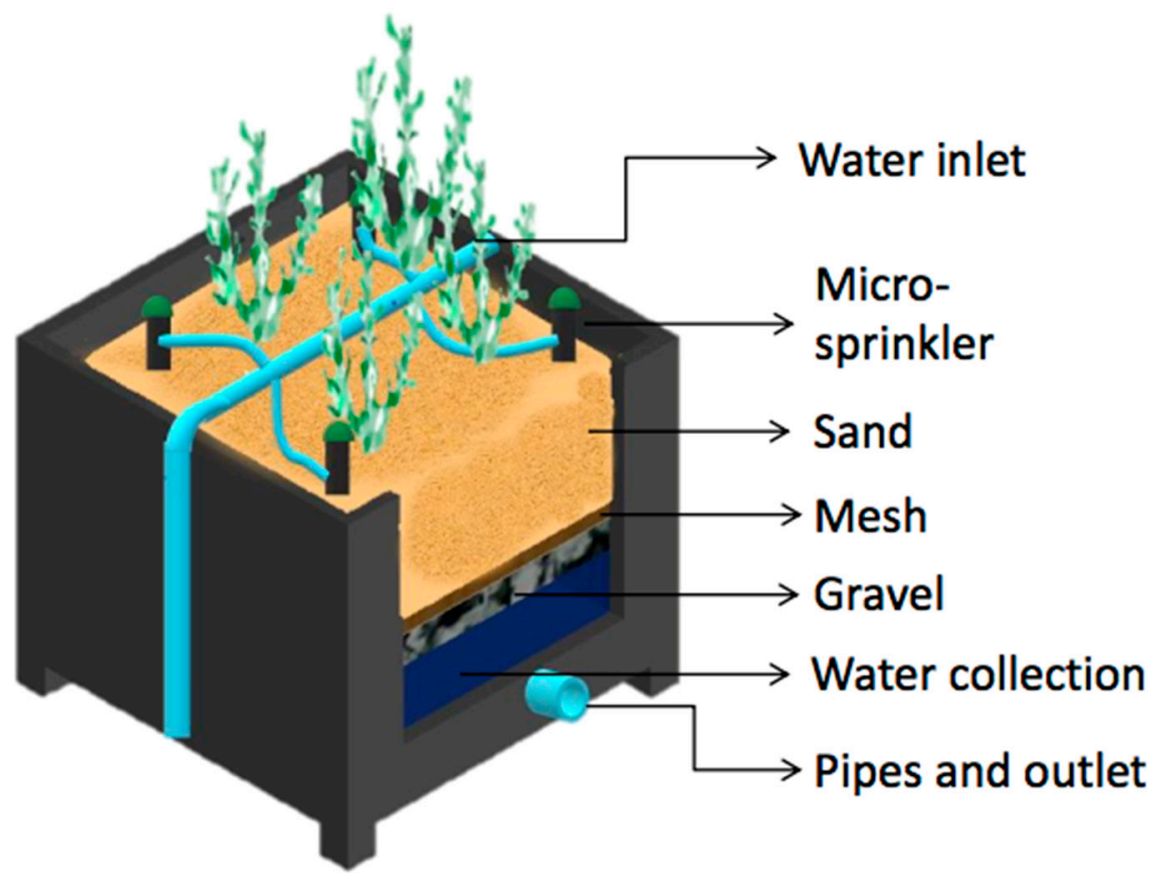

Figure 1. The diagram shows the design of one lysimeter, depicting the overall construction, water inlet and outlet, substrate (sand and gravel separated by a mesh), and irrigation micro-sprinklers.

\subsection{Experimental Design}

The S. neei performance regarding removal of nitrogen compounds and biomass production was evaluated for 74 days under three irrigation treatments: (1) seawater fertilized with nitrate- $\mathrm{N}+$ ammonium-N (Nit + Amm); (2) seawater fertilized with nitrate-N (Nit); and (3) seawater without fertilizer that was used as a control group (Control). The nutrient concentrations in each irrigation water supply were designed according to the typical average concentrations of ammonium-N $\left(\mathrm{NH}_{4}{ }^{+}-\mathrm{N}\right)$ and nitrate $\left(\mathrm{NO}_{3}{ }^{-} \mathrm{N}\right)$ reported in land-based marine aquaculture effluent [31,32]. The following concentrations were used: $\mathrm{Nit}+\mathrm{Amm}=1 \mathrm{mg} \mathrm{L}^{-1}$ of total ammonia nitrogen (TAN) and $100 \mathrm{mg}$ $\mathrm{L}^{-1}$ of $\mathrm{NO}_{3}{ }^{-} \mathrm{N}$; Nit $=100 \mathrm{mg} \mathrm{L}^{-1}$ of $\mathrm{NO}_{3}{ }^{-} \mathrm{N}$; and Control $=$ no fertilizer. The nutrient solution for each RAS was prepared directly in each collection tank and completely renewed every 14-15 days. Five repetitions or inputs were performed during the 74 days of culture.

The physico-chemical parameters of water quality were recorded directly from the drainage water during the first eight consecutive days after nutrient addition. The estimation of $\mathrm{NO}_{3}{ }^{-} \mathrm{N}$ concentration was performed using the cadmium reduction method. $\mathrm{NO}_{3}{ }^{-} \mathrm{N}$ removal efficiency (RE) was calculated as: $\mathrm{RE}=(\mathrm{Ci}-\mathrm{Co}) / \mathrm{Ci} \times 100$ where: $\mathrm{Ci}=$ concentration of $\mathrm{NO}_{3}{ }^{-} \mathrm{N}$ in the influent water at day 1 ; and $\mathrm{Co}=$ concentration of $\mathrm{NO}_{3}{ }^{-} \mathrm{N}$ in the effluent water at day 8 from each input. Additionally, temperature, oxygen, conductivity, salinity, and $\mathrm{pH}$ were measured as water quality indicators. These parameters were measured using a HACH multiparameter probe (HQ40). Biomass (fresh weight) was recorded at the beginning and at the end of the experiment using a scale (Jadever, JWE-6K). The data on ambient temperature, rainfall, and relative humidity were sourced from climate records of the Chilean Meteorological Office (Torquemada-Viña del Mar Station).

\subsection{Statistical Analysis}

Biomass was compared using a two-way ANOVA in R Statistical Software [33], with interaction between nitrogen simulated concentrations (3 levels: Nit + Amm, Nit, and Control) and days of culture (two levels: 0 and 74 days) (Supplementary Table S1). To compare group means we performed post hoc Tukey tests (Supplementary Table S2) in R Statistical Software [33]. The change in nitrate-nitrogen $\left(\mathrm{NO}_{3}{ }^{-} \mathrm{N}\right)$ concentration showed a negative nonlinear relationship over time, therefore the linear 
removal rate (RR) was calculated separately for days 1 to 4 and days 5 to 8 of each input, when linearity was observed. Linear regression models with a respondent (dependent) variable of nitrate-nitrogen $\left(\mathrm{NO}_{3}{ }^{-} \mathrm{N}\right)$ concentration and predictor variables of days of culture and nitrogen simulated concentrations were performed using the " $1 \mathrm{~m}$ " function in R Statistical Software [33]. Probabilities of $p<0.05$ were considered significant.

\section{Results}

\subsection{Environmental Conditions and RAS Parameters}

During the 74 days of culture, the ambient temperature and relative humidity conditions and the temperature, $\mathrm{pH}$, and salinity of the cultivation system showed different levels of variability, and no rainfall was recorded during the experiment. The ambient temperature had a mean of $16 \pm 4{ }^{\circ} \mathrm{C}$ but was highly variable during the day, with extreme values of 9 and $31^{\circ} \mathrm{C}$, and the relative humidity was $77.8 \% \pm 8.7 \%$, with extreme values of $60 \%$ and $95 \%$ (Supplementary Figure S1). The temperature in the culture systems was usually higher than the ambient temperature, with a mean of $20.5 \pm 1.24{ }^{\circ} \mathrm{C}$ and a range of 19.1 to $21.7^{\circ} \mathrm{C}$, with no observed differences between treatments (Table 1). The $\mathrm{pH}$ remained relatively constant and without differences between treatments, whereas the salinity had a noticeable increase from a mean of $40 \mathrm{~g} \mathrm{~L}^{-1}$ of $\mathrm{NaCl}$ on day 1 to a mean of $51.5 \pm 0.19 \mathrm{~g} \mathrm{~L}^{-1} \mathrm{of} \mathrm{NaCl}$ at the end of the experiment (Table 1). No significant differences in salinity between treatments were observed $(p<0.05)$.

Table 1. Recirculating aquaculture system (RAS) physicochemical parameters measured for the effluent.

\begin{tabular}{ccccc}
\hline Treatment & Input & $\begin{array}{c}\text { Temperature } \\
\left({ }^{\circ} \mathbf{C}\right)\end{array}$ & $\mathbf{p H}$ & $\begin{array}{c}\text { Salinity } \\
\left(\mathbf{g ~ L ~}^{-1} \mathbf{)}\right.\end{array}$ \\
\hline \multirow{3}{*}{ Nit + Amm } & 1 & $18.2 \pm 4.2$ & $8.2 \pm 0.1$ & $40.6 \pm 2.2$ \\
& 2 & $18.8 \pm 1.6$ & $8.1 \pm 0.1$ & $44.9 \pm 2.3$ \\
& 3 & $20.8 \pm 0.6$ & $7.9 \pm 0.1$ & $48.5 \pm 2.5$ \\
& 4 & $20.2 \pm 1.2$ & $8.0 \pm 0.1$ & $47.5 \pm 1.9$ \\
Nit & 5 & $20.6 \pm 0.6$ & $8.0 \pm 0.1$ & $48.0 \pm 2.2$ \\
\hline & 1 & $19.5 \pm 4.7$ & $8.2 \pm 0.1$ & $41.3 \pm 1.9$ \\
& 2 & $21.7 \pm 3.3$ & $8.1 \pm 0.1$ & $48.4 \pm 2.2$ \\
& 3 & $21.2 \pm 0.8$ & $7.9 \pm 0.1$ & $48.8 \pm 3.2$ \\
Control & 5 & $20.6 \pm 1.4$ & $8.0 \pm 0.1$ & $47.5 \pm 2.1$ \\
& 1 & $20.9 \pm 0.7$ & $7.9 \pm 0.1$ & $47.7 \pm 2.4$ \\
\hline & 2 & $19.1 \pm 4.3$ & $8.2 \pm 0.1$ & $40.0 \pm 0.0$ \\
& 3 & $18.6 \pm 1.5$ & $8.0 \pm 0.1$ & $43.6 \pm 2.1$ \\
& 4 & $20.8 \pm 0.5$ & $8.0 \pm 0.1$ & $43.6 \pm 2.1$ \\
& 5 & $20.3 \pm 1.2$ & $8.2 \pm 0.1$ & $46.5 \pm 2.6$ \\
& $20.7 \pm 0.5$ & $8.2 \pm 0.1$ & $46.5 \pm 1.6$ \\
\hline
\end{tabular}

Temperature, $\mathrm{pH}$, and salinity (mean $\pm \mathrm{SE}$ ) recorded for the effluent of the culture systems with Salicornia neei. Salinity is expressed as grams of natrium chloride per liter $\left(\mathrm{g} \mathrm{L}^{-1}\right)$. Treatments were irrigated with nitrate-N and ammonium-N (Nit + Amm), nitrate-N (Nit), or with sea water only (Control group). Each input corresponds to a new irrigation with nitrate-N and ammonium-N (Nit+Amm), or nitrate-N (Nit). Mean values of three lysimeters per treatment are displayed $( \pm \mathrm{EE})$.

\subsection{Growth and Biomass Formation}

Regarding biomass production, the treatments with Nit + Amm and Nit showed a significant increase in fresh weight from $3.0 \pm 0.6 \mathrm{~g}$ to $11.3 \pm 2.0 \mathrm{~kg} \mathrm{~m}^{-2}$ and from $3.4 \pm 0.1 \mathrm{~g}$ to $10.0 \pm 0.8 \mathrm{~kg} \mathrm{~m}^{-2}$, respectively (Figure 2). Although the plants grew in the control group, this increase in biomass was not significant $(p=0.61)$. Plants irrigated with seawater presented chlorosis and accumulation of pigment in leaf tissue, probably anthocyanin, which indicated moderate stress on the plant, however, this phenomenon was not observed in either of the two nitrogen treatments (Figure 3). 


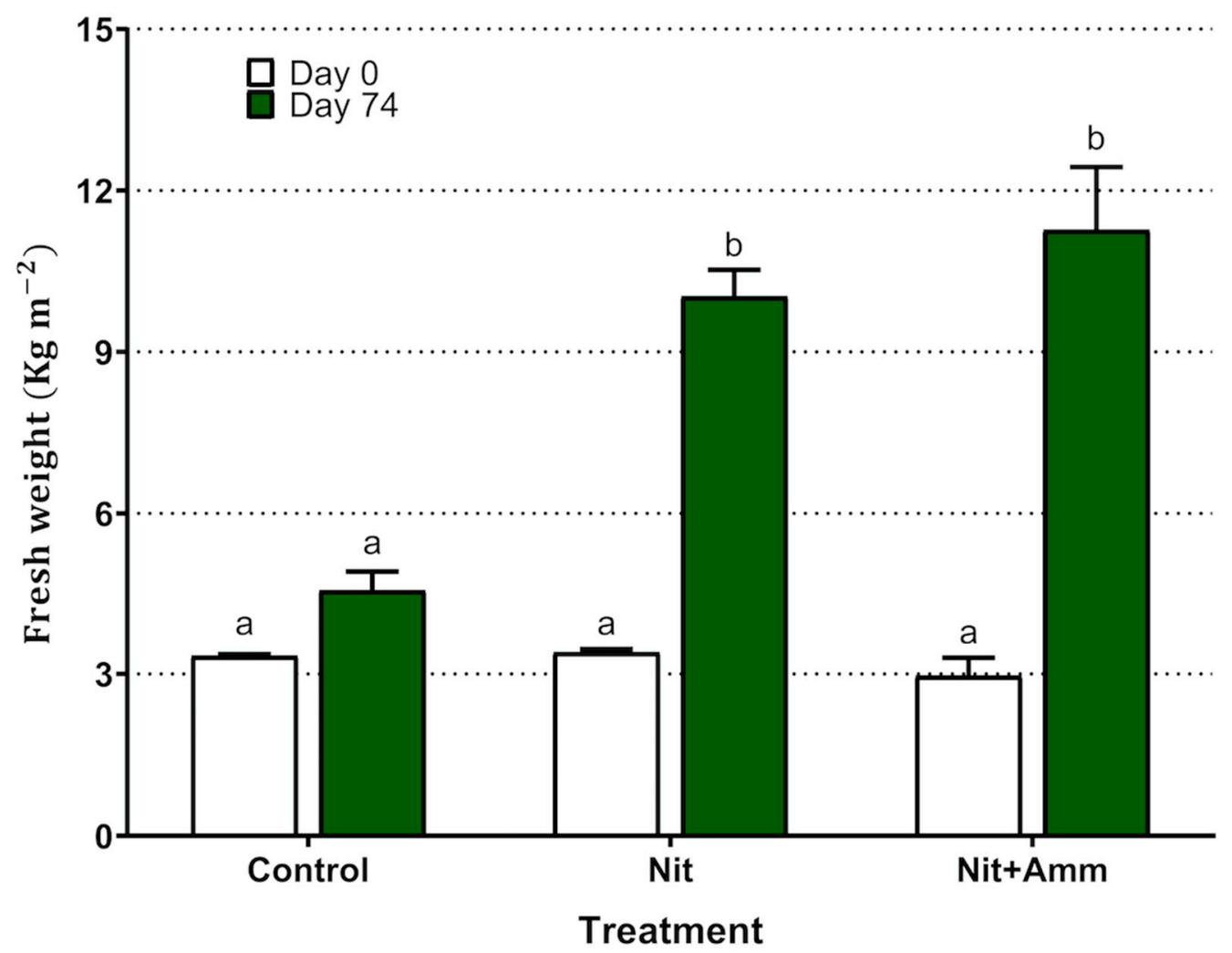

Figure 2. Production of biomass of Salicornia neei by treatment expressed as yield of fresh weight per area unit $\left(\mathrm{kg} \mathrm{m}^{-2}\right)$. Nit + Amm: corresponds to the treatments irrigated with nitrate-N and ammonium-N, Nit: irrigated with nitrate-N, Control: treatment irrigated with sea water only. Lower-case letters represent significant differences between treatments. Mean values of three lysimeters per treatment are displayed $( \pm \mathrm{EE})$.

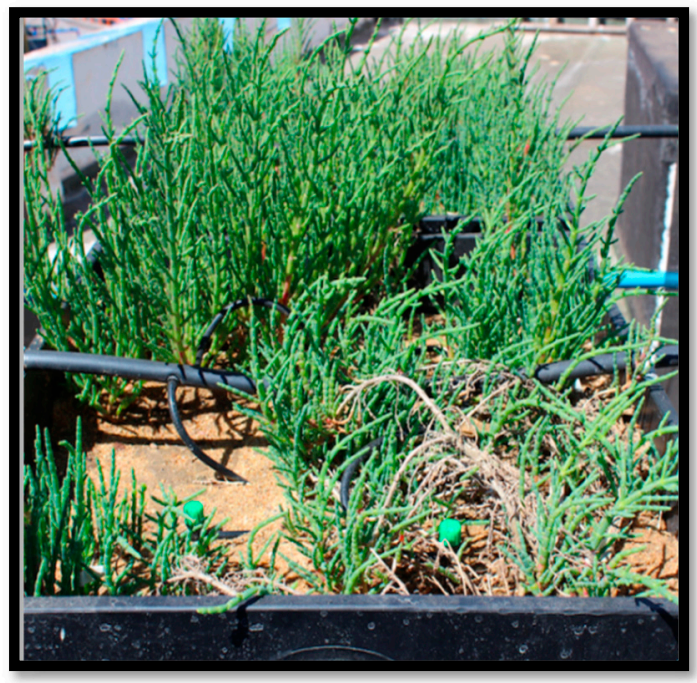

(a)

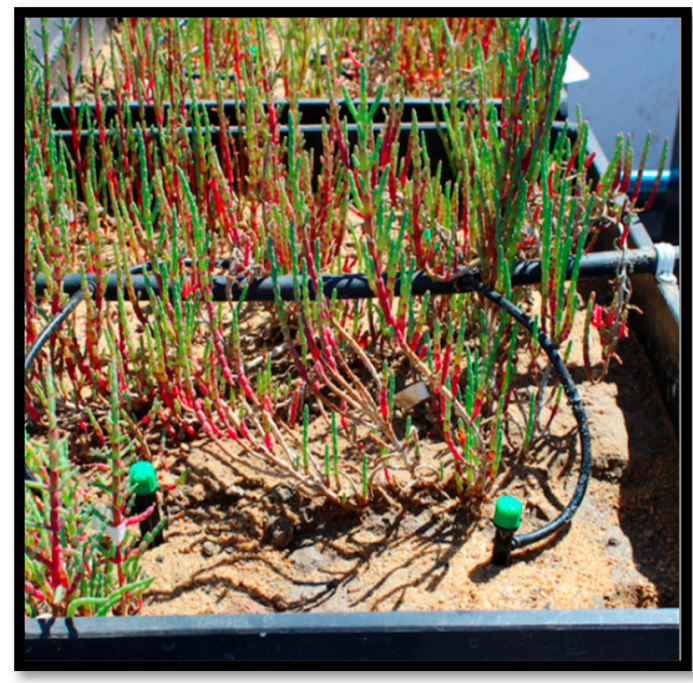

(b)

Figure 3. Picture of two lysimeters with Salicornia neei at the end of the experiment (day 74). Picture (a) plants irrigated with nitrate and ammonium (Nit + Amm). Picture (b) plants irrigated with sea-water (Control). 


\subsection{Efficiency of Salicornia neei to Treat Saline Effluent}

Nitrate-N removal was nonlinear and concentration-dependent for treatments Nit $+\mathrm{Amm}$ and $\mathrm{Nit}$ (Figure 4). Thus, nitrate-N removal rates (RR) were reduced when nitrogen loading was reduced from $2.9 \pm 0.3 \mathrm{mg} \mathrm{L}^{-1} \mathrm{~d}^{-1}\left(\mathrm{RR}_{\text {day1-4 }}\right)$ to $0.8 \pm 0.2 \mathrm{mg} \mathrm{L}^{-1} \mathrm{~d}^{-1}\left(\mathrm{RR}_{\text {day5-8 }}\right)$ in the treatment $\mathrm{Nit}+\mathrm{Amm}$, and from $2.4 \pm 0.5 \mathrm{mg} \mathrm{L}^{-1} \mathrm{~d}^{-1}\left(\mathrm{RR}_{\text {day1-4}}\right)$ to $1.0 \pm 0.2 \mathrm{mg} \mathrm{L}^{-1} \mathrm{~d}^{-1}\left(\mathrm{RR}_{\text {day5-8}}\right)$ in the treatment Nit (Table 2). In contrast, nitrate-N removal rates measured between days 1 and $4\left(R_{\text {day1-4 }}\right)$ had a clear tendency to increase bacause biomass production increased using the treatment Nit but not in the treatment Nit + Amm (Table 2), which is perhaps explained by the greater availability of nitrogen in this last treatment. Without considering these differences in both treatments, the nitrogen removal efficiency was high in each treatment, in and throughout the crop, and varied between $87 \%$ and $92 \%$ (Table 2). Effluent salinity increased from 40.6 to $49.4 \mathrm{~g} \mathrm{~L}^{-1}$ during the experiment, with no observed detrimental effects on the nitrate-N removal rates or on the nitrogen removal efficiency.

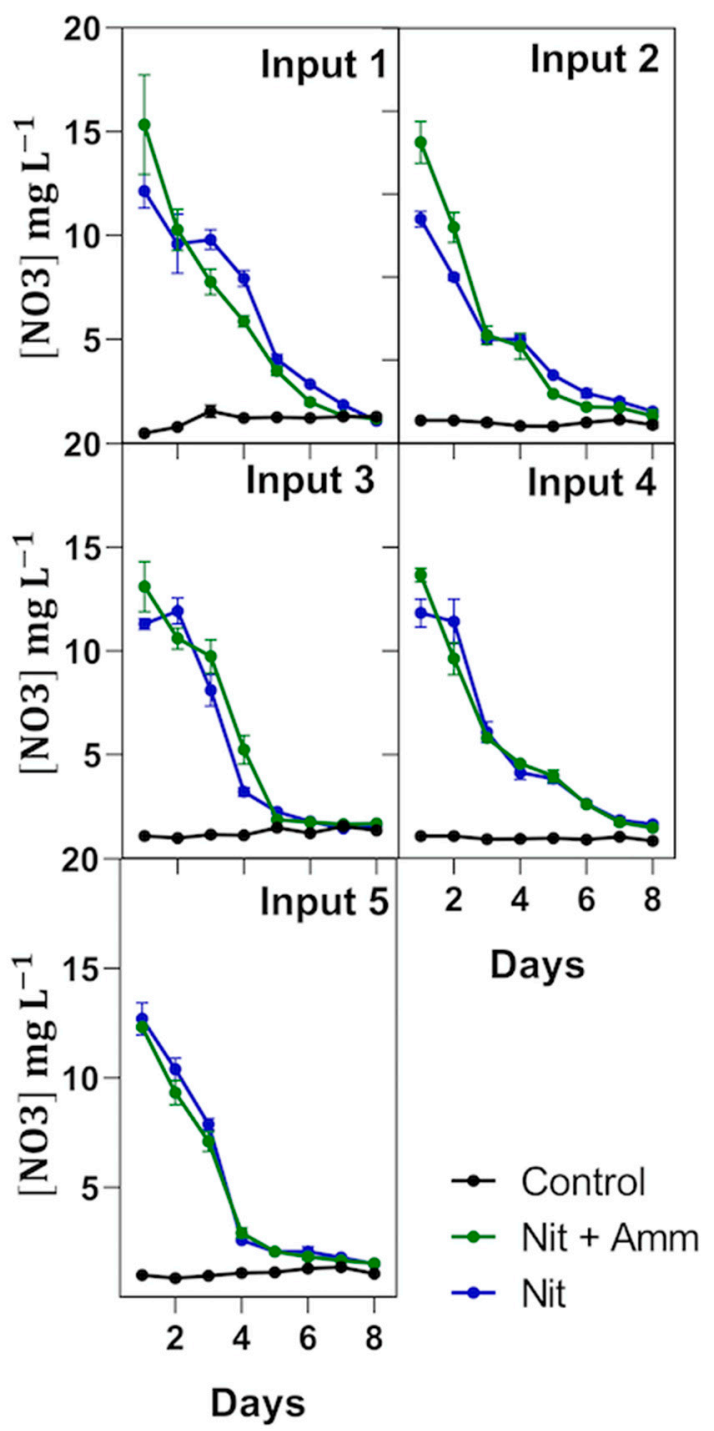

Figure 4. Nitrogen removal by treatment and input. Nitrate-nitrogen $\left(\mathrm{NO}_{3}{ }^{-} \mathrm{N}\right)$ concentration in each treatment is expressed in $\mathrm{mg} \mathrm{L}^{-1}$ and measured during an 8 day period from nutrient input over 74 days of experimentation. Treatments were irrigated with nitrate- $\mathrm{N}$ and ammonium-N (Nit + Amm), nitrate-N (Nit), or with sea water only (Control group). Each input corresponds to a new irrigation with nitrate-N and ammonium-N (Nit + Amm) or nitrate-N (Nit). Mean values of three lysimeters per treatment are displayed $( \pm \mathrm{SE})$. 
Table 2. Nitrate-nitrogen $\left(\mathrm{NO}_{3}{ }^{-} \mathrm{N}\right)$ concentration in the influent water at day $1(\mathrm{Ci})$ and in the effluent at day $8(\mathrm{Co})$, removal efficiency (RE) and removal rate (RR) for each treatment irrigated with nitrate-N and ammonium-N (Nit + Amm) and nitrate-N (Nit). Each input corresponds to a new irrigation with nitrate-N and ammonium-N (Nit + Amm) or nitrate-N (Nit). Each input has three lysimeters per treatment. Treatments were irrigated with nitrate- $\mathrm{N}$ and ammonium-N (Nit + Amm) and nitrate-N (Nit). Mean values of three lysimeters per treatment are displayed $( \pm \mathrm{SE})$.

\begin{tabular}{|c|c|c|c|c|c|c|}
\hline Treatment & Input & $\begin{array}{c}\mathrm{Ci} \\
\left(\mathrm{mg} \mathrm{L}^{-1}\right)\end{array}$ & $\begin{array}{c}\text { Co } \\
\left(\mathrm{mg} \mathrm{L}^{-1}\right)\end{array}$ & $\begin{array}{l}\mathrm{RE} \\
(\%)\end{array}$ & $\begin{array}{c}\text { RR } \\
\text { Day } 1-4 \\
\left(\mathrm{mg} \mathrm{L}^{-1} \mathrm{~d}^{-1}\right)\end{array}$ & $\begin{array}{c}\text { RR } \\
\text { Day 5-8 } \\
\left(\mathrm{mg} \mathrm{L}^{-1} \mathrm{~d}^{-1}\right)\end{array}$ \\
\hline \multirow{6}{*}{$\mathrm{Nit}+\mathrm{Amm}$} & 1 & $14.0 \pm 4.2$ & $1.2 \pm 0.1$ & 91.4 & $2.9 \pm 0.5$ & $1.2 \pm 0.1$ \\
\hline & 2 & $17.7 \pm 2.2$ & $1.8 \pm 0.7$ & 89.8 & $2.0 \pm 0.3$ & $0.3 \pm 0.1$ \\
\hline & 3 & $13.5 \pm 0.6$ & $1.1 \pm 0.05$ & 91.9 & $3.1 \pm 0.3$ & $0,8 \pm 0.1$ \\
\hline & 4 & $12.9 \pm 2.1$ & $1.7 \pm 0.1$ & 86.8 & $3.6 \pm 0.5$ & $0.0 \pm 0.0$ \\
\hline & 5 & $12.4 \pm 0.1$ & $1.5 \pm 0.1$ & 87.9 & $3.0 \pm 0.2$ & $0.0 \pm 0.0$ \\
\hline & & & Mean & $89.6 \pm 1.0$ & $2.3 \pm 0.4$ & $0.5 \pm 0.2$ \\
\hline \multirow[t]{6}{*}{ Nit } & 1 & $12.0 \pm 1.4$ & $1.1 \pm 0.1$ & 90.8 & $1.1 \pm 0.5$ & $1.4 \pm 0.1$ \\
\hline & 2 & $13.3 \pm 0.8$ & $1.8 \pm 0.2$ & 86.5 & $1.2 \pm 0.3$ & $0.6 \pm 0.1$ \\
\hline & 3 & $12.4 \pm 1.2$ & $1.2 \pm 0.15$ & 90.3 & $2.8 \pm 0.3$ & $0.7 \pm 0.1$ \\
\hline & 4 & $13.2 \pm 1.0$ & $1.6 \pm 0.1$ & 87.9 & $3.7 \pm 0.5$ & $0.2 \pm 0.0$ \\
\hline & 5 & $13.0 \pm 1.3$ & $1.5 \pm 0.0$ & 88.5 & $3.3 \pm 0.2$ & $0.0 \pm 0.0$ \\
\hline & & & Mean & $88.8 \pm 0.9$ & $2.9 \pm 0.5$ & $0.4 \pm 0.2$ \\
\hline
\end{tabular}

\section{Discussion}

The integration of halophytes as a biofilter in recirculating systems in marine aquaculture has been proposed as an adequate alternative to decontaminating water with increased nitrogen compounds [34]. In this study we evaluated if artificial wetlands of $S$. neei could be used to treat saline aquaculture effluent. S. neei was selected mainly due to its natural occurrence throughout much of the South Pacific coast of South America [35], which would allow its rapid adoption in the growing South American aquaculture. The nitrate-nitrogen removal rate and removal efficiency recorded in this study (Table 2) were higher than or similar to those reported with other halophyte species in high salinity [14,15]. Thus, artificial wetlands of $S$. neei could be a good alternative for the treatment of highly concentrated wastewater released in marine RASs.

Physicochemical parameters of the effluent, such as temperature and $\mathrm{pH}$, are especially important in the treatment of saline wastewater because they can affect the determinant processes in the removal of nitrogen compounds [36]. In this study, temperature and $\mathrm{pH}$ were maintained within the optimal ranges (20-21 ${ }^{\circ} \mathrm{C}$ and 7.8-8.2, respectively) and therefore did not affect the nutrient removal processes (Table 1 ). This finding is consistent with Lee et al. [37], who reported that, for denitrification processes in wetland systems, the optimal temperature ranges between 20 and $40{ }^{\circ} \mathrm{C}$ and the optimal $\mathrm{pH}$ is approximately 8.0. Another important parameter evaluated in this study was the high effluent salinity, which reached concentrations of up to $50 \mathrm{~g} \mathrm{~L}^{-1}$ of $\mathrm{NaCl}$. This increase was mainly due to the known environmental factor of evapotranspiration, consistent with a study by Freedman et al. [38], who found increased salinity of treated water in artificial wetlands despite the salt uptake by plants due to soil evaporation and plant transpiration.

Nitrogen bioaccumulation was not determined empirically in this study, but we derived it from Riquelme et al. [22], a previous study performed by our research group. Riquelme et al. [22] show that the total of $\mathrm{N}$ fixed in the aerial part of $S$. neei corresponds to $1.76 \pm 0.08 \mathrm{~g}$ per $100 \mathrm{~g}$ of fresh weight. Similar results were obtained in Salicornia brachiata by Rathore et al. [39] from India. Thus, we estimated that the total concentration of nitrogenous nutrients fixed in S. neei at the end of the trial would be between 46 and $103.9 \mathrm{~g}$ for the Nit treatment, whereas for Nit + Amm, the fixation would be between 57.8 and $130.1 \mathrm{~g}$ of $\mathrm{N}$ for the total biomass formed by this treatment, indicating that $S$. neei could assimilate most of the nitrogen available in this test. According to these results, it can also be 
suggested that $S$. neei can store ammonium-N, if the differences of the estimates in the two treatments are considered (approximately $20 \%$ more $\mathrm{N}$ with the Nit + Amm treatment). This reflects the synergy produced by these two compounds when consumed at the same time [40]. However some researchers currently believe that the actual absorption may represent only a relatively small fraction of the global rate of nitrogen $(\mathrm{N})$ elimination [41], and microorganisms have the most important role in the use and transformation of nitrogen component [42].

In response to this uncertainty, other researchers have studied and obtained low removal rates by plants. Specifically, Tanner et al. [43] found that of the total nitrogen removed by planted wetland systems, only $25 \%$ corresponded to fixation in plants. Similarly, Lin et al. [32] observed that, of the $73 \%$ of nitrogen removed, only $11 \%$ was fixed in plants. Notwithstanding the above, Webb et al. [25] observed significant differences between the nitrogen removal capacity in beds planted with and without halophytes. In their study, they demonstrated a higher removal yield in planted beds $\left(62.0 \pm 34.6 \mathrm{mmol} \mathrm{N} \mathrm{m}^{-2} \mathrm{~d}^{-1}\right)$ than in unplanted beds $\left(23.0 \pm 26.8 \mathrm{mmol} \mathrm{N} \mathrm{m}^{-2} \mathrm{~d}^{-1}\right)$. This is consistent with our results that show nitrogen removal is proportional to biomass. Therefore, we cannot rule out that the increase in biomass exclusively explains the increase in the nitrate removal rate. In fact, it is plausible that a strong root system formed by this class of plants supports the establishment of certain microorganisms that improve the removal rate of nitrogen loads by acting synergistically.

The formation of $S$. neei biomass during the evaluation period reached a total net weight of $7-8 \mathrm{~kg} \mathrm{~m}^{-2}$ over a period of eleven weeks in the treatments irrigated Nit and Nit + Amm respectively. These high yields in biomass production are comparable to those obtained by Ventura et al. [44], whose yields for Salicornia persica reached $16 \mathrm{~kg} \mathrm{~m}^{-2}$ in a span of 24 weeks. By comparison, S. neei plants remained vigorous throughout the evaluation period, even at high salinity concentrations close to $50 \mathrm{~g} \mathrm{~L}^{-1}$ of NaCl. This inherent feature of halophytes highlights the powerful response mechanisms to abiotic stress triggered by $S$. neei, reinforcing the feasibility of including this plant for aquaculture effluent treatment. Regarding removal of the two sources of nitrogen compounds, there was a positive interaction between the ammonium/nitrate supplied for biomass formation of $S$. neei. This positive interaction could be caused by the contribution of the nitrate ion that acts as an important osmotic anion for expansion of the foliar cells [45].

\section{Conclusions}

Our results reveal that the integration of $S$. neei into artificial wetlands with recirculating aquaculture effluent would be a viable alternative for eliminating nutrient loads in saline wastewater and that this plant could be included in marine RASs in South America.

Supplementary Materials: The following are available online at http:/www.mdpi.com/2077-0472/10/12/621/ s1, Figure S1: Ambient temperature $\left({ }^{\circ} \mathrm{C}\right)$ and relative humidity $(\% \mathrm{RH})$ during the date of experimentation, Table S1: Two-way ANOVA. For quantitative biomass growth data, the effect of treatment versus Days of culture were analyzed by two-way ANOVA test, Table S2: Tukey test (HSD). Tukey multiple comparisons of means $95 \%$ familywise confidence level.

Author Contributions: All co-authors have fully participated in and accept responsibility for the work. This publication is approved by all authors and the responsible authorities where the work was carried out. The authors declare that they have no competing interests, and ensure that the work was appropriately investigated, resolved, and documented in the literature. Conceptualization, J.A.G. and J.O.; methodology, J.A.G. and J.O.; software, M.R.D.; validation, J.A.G. and M.R.D.; formal analysis, M.R.D.; investigation, M.R.D., A.O., J.A.; data curation, M.R.D.; writing-original draft preparation, J.A.G. and M.R.D.; writing-review and editing, J.A.G. and J.O.; visualization, M.R.D.; project administration, J.A.G.; funding acquisition, J.A.G. and J.O. All authors have read and agreed to the published version of the manuscript.

Funding: GOBIERNO REGIONAL DE VALPARAÍSO, CHILE, grant number FIC BIP 30154272.

Acknowledgments: The authors wish to thank Aldo Madrid and Marine Farms Inc. for his technical assistance and support during the project. M.R.D. was supported by a Doctoral fellowship by the "Dirección General de Investigación y Postgrado" of the Universidad Técnica Federico Santa María.

Conflicts of Interest: All authors declare that there are no present or potential conflicts of interest among the authors and other people or organizations that could inappropriately bias their work. 


\section{References}

1. Tovar, A.; Moreno, C.; Manuel-Vez, M.P.; Garcia-Vargas, M. Environmental impacts of intensive aquaculture in marine waters. Water Res. 2000, 34, 334-342. [CrossRef]

2. De Lange, H.J.; Paulissen, M.; Slim, P.A. Halophyte filters: The potential of constructed wetlands for application in saline aquaculture. Int. J. Phytoremediat. 2013, 15, 352-364. [CrossRef] [PubMed]

3. Quinta, R.; Santos, R.; Thomas, D.N.; Le Vay, L. Growth and nitrogen uptake by Salicornia europaea and Aster tripolium in nutrient conditions typical of aquaculture wastewater. Chemosphere 2015, 120, 414-421. [CrossRef] [PubMed]

4. Vymazal, J. Constructed wetlands for treatment of industrial wastewaters: A review. Ecol. Eng. 2014, 73, 724-751. [CrossRef]

5. Boxman, S.E.; Nystrom, M.; Capodice, J.C.; Ergas, S.J.; Main, K.L.; Trotz, M.A. Effect of support medium, hydraulic loading rate and plant density on water quality and growth of halophytes in marine aquaponic systems. Aquac. Res. 2017, 48, 2463-2477. [CrossRef]

6. Carballeira, C.; de Orte, M.R.; Viana, I.G.; Carballeira, A. Implementation of a minimal set of biological tests to assess the ecotoxic effects of effluents from land-based marine fish farms. Ecotox. Environ. Safe. 2012, 78, 148-161. [CrossRef]

7. Shpigel, M.; Ben-Ezra, D.; Shauli, L.; Sagi, M.; Ventura, Y.; Samocha, T. Constructed wetland with Salicornia as a biofilter for mariculture effluents. Aquaculture 2013, 412, 52-63. [CrossRef]

8. Zohar, Y.; Tal, Y.; Schreier, H.; Steven, C.; Stubblefield, J.; Place, A. 10 Commercially Feasible Urban Recirculating Aquaculture: Addressing the Marine Sector; Costa-Pierce, B., Desbonnet, A., Edwards, P., Baker, D., Eds.; CABI Publishing: Wallingford, UK, 2005; pp. 159-171.

9. Gutierrez-Wing, M.T.; Malone, R.F. Biological filters in aquaculture: Trends and research directions for freshwater and marine applications. Aquac. Eng. 2006, 34, 163-171. [CrossRef]

10. Kajimura, M.; Croke, S.J.; Glover, C.N.; Wood, C.M. Dogmas and controversies in the handling of nitrogenous wastes: The effect of feeding and fasting on the excretion of ammonia, urea and other nitrogenous waste products in rainbow trout. J. Exp. Biol. 2004, 207, 1993-2002. [CrossRef]

11. Camargo, J.A.; Alonso, A. Ecological and toxicological effects of inorganic nitrogen pollution in aquatic ecosystems: A global assessment. Environ. Int. 2006, 32, 831-849. [CrossRef]

12. Thoman, E.S.; Ingall, E.D.; Davis, D.A.; Arnold, C.R. A nitrogen budget for a closed, recirculating mariculture system. Aquac. Eng. 2001, 24, 195-211. [CrossRef]

13. Orellana, J.; Waller, U.; Wecker, B. Culture of yellowtail kingfish (Seriola lalandi) in a marine recirculating aquaculture system (RAS) with artificial seawater. Aquac. Eng. 2014, 58, 20-28. [CrossRef]

14. Brown, J.J.; Glenn, E.P.; Fitzsimmons, K.M.; Smith, S.E. Halophytes for the treatment of saline aquaculture effluent. Aquaculture 1999, 175, 255-268. [CrossRef]

15. Webb, J.M.; Quinta, R.; Papadimitriou, S.; Norman, L.; Rigby, M.; Thomas, D.N. Halophyte filter beds for treatment of saline wastewater from aquaculture. Water Res. 2012, 46, 5102-5114. [CrossRef] [PubMed]

16. Buhmann, A.; Papenbrock, J. Biofiltering of aquaculture effluents by halophytic plants: Basic principles, current uses and future perspectives. Environ. Exp. Bot. 2013, 92, 122-133. [CrossRef]

17. Forde, B.G.; Clarkson, D.T. Nitrate and ammonium nutrition of plants: Physiological and molecular perspectives. Adv. Bot. Res. 1999, 30, 1-90.

18. Cott, G.M.; Caplan, J.S.; Mozdzer, T.J. Nitrogen uptake kinetics and saltmarsh plant responses to global change. Sci. Rep. 2018, 8, 5393. [CrossRef]

19. Hessini, K.; Ben Hamed, K.; Gandour, M.; Mejri, M.; Abdelly, C.; Cruz, C. Ammonium nutrition in the halophyte Spartina alterniflora under salt stress: Evidence for a priming effect of ammonium? Plant. Soil. 2013, 370, 163-173. [CrossRef]

20. Jesus, J.M.; Cassoni, A.C.; Danko, A.S.; Fiuza, A.; Borges, M.T. Role of three different plants on simultaneous salt and nutrient reduction from saline synthetic wastewater in lab-scale constructed wetlands. Sci. Total Environ. 2017, 579, 447-455. [CrossRef]

21. Panta, S.; Flowers, T.; Lane, P.; Doyle, R.; Haros, G.; Shabala, S. Halophyte agriculture: Success stories. Environ. Exp. Bot. 2014, 107, 71-83. [CrossRef] 
22. Riquelme, J.; Olaeta, J.A.; Galvez, L.; Undurraga, P.; Fuentealba, C.; Osses, A. Nutritional and functional characterization of wild and cultivated Sarcocornia neei grown in Chile. Cienc. Investig. Agrar. 2016, 43, $283-293$. [CrossRef]

23. Turcios, A.E.; Papenbrock, J. Sustainable treatment of aquaculture effluents-what can we learn from the Past for the future? Sustainability 2014, 6, 836-856. [CrossRef]

24. Vymazal, J. Constructed wetlands for wastewater treatment. Ecol. Eng. 2005, 25, 475-477. [CrossRef]

25. Webb, J.M.; Quinta, R.; Papadimitriou, S.; Norman, L.; Rigby, M.; Thomas, D.N. The effect of halophyte planting density on the efficiency of constructed wetlands for the treatment of wastewater from marine aquaculture. Ecol. Eng. 2013, 61, 145-153. [CrossRef]

26. Quinta, R.; Hill, P.W.; Jones, D.L.; Santos, R.; Thomas, D.N.; Le Vay, L. Uptake of an amino acid (alanine) and its peptide (trialanine) by the saltmarsh halophytes Salicornia europaea and Aster tripolium and its potential role in ecosystem $\mathrm{N}$ cycling and marine aquaculture wastewater treatment. Ecol. Eng. 2015, 75, 145-154. [CrossRef]

27. Waller, U.; Buhmann, A.K.; Ernst, A.; Hanke, V.; Kulakowski, A.; Wecker, B. Integrated multi-trophic aquaculture in a zero-exchange recirculation aquaculture system for marine fish and hydroponic halophyte production. Aquac. Int. 2015, 23, 1473-1489. [CrossRef]

28. Valladao, G.M.R.; Gallani, S.U.; Pilarski, F. South American fish for continental aquaculture. Rev. Aquac. 2018, 10, 351-369. [CrossRef]

29. Alonso, M.F.; Orellana, C.; Valdes, S.; Diaz, F.J. Effect of salinity on the germination of Sarcocornia neei (Chenopodiaceae) from two contrasting habitats. Seed Sci. Technol. 2017, 45, 252-258. [CrossRef]

30. De Souza, M.M.; Mendes, C.R.; Doncato, K.B.; Badiale-Furlong, E.; Costa, C.S.B. Growth, phenolics, photosynthetic pigments, and antioxidant response of two new genotypes of sea Asparagus (Salicornia neei Lag.) to salinity under greenhouse and field conditions. Agriculture 2018, 8, 115. [CrossRef]

31. De Lange, H.J.; Paulissen, M. Efficiency of three halophyte species in removing nutrients from saline water: A pilot study. Wetl. Ecol. Manag. 2016, 24, 587-596. [CrossRef]

32. Lin, Y.F.; Jing, S.R.; Lee, D.Y.; Wang, T.W. Nutrient removal from aquaculture wastewater using a constructed wetlands system. Aquaculture 2002, 209, 169-184. [CrossRef]

33. Team R.C. R: A Language and Environment for Statistical Computing, R Foundation for Statistical Computing. Available online: https://www.R-project.org/ (accessed on 31 March 2020).

34. El Shaer, H.M. Halophytes and salt-tolerant plants as potential forage for ruminants in the Near East region. Small. Ruminant. Res. 2010, 91, 3-12. [CrossRef]

35. Alonso, M.A.; Crespo, M.B. Taxonomic and nomenclatural notes on South American taxa of Sarcocornia (Chenopodiaceae). Ann. Bot. Fenn. 2008, 45, 241-254. [CrossRef]

36. Liang, Y.X.; Zhu, H.; Banuelos, G.; Yan, B.X.; Zhou, Q.W.; Yu, X.F. Constructed wetlands for saline wastewater treatment: A review. Ecol. Eng. 2017, 98, 275-285. [CrossRef]

37. Lee, C.G.; Fletcher, T.D.; Sun, G.Z. Nitrogen removal in constructed wetland systems. Eng. Life. Sci. 2009, 9, 11-22. [CrossRef]

38. Freedman, A.; Gross, A.; Shelef, O.; Rachmilevitch, S.; Arnon, S. Salt uptake and evapotranspiration under arid conditions in horizontal subsurface flow constructed wetland planted with halophytes. Ecol. Eng. 2014, 70, 282-286. [CrossRef]

39. Rathore, A.P.; Chaudhary, D.R.; Jha, B. Biomass production, nutrient cycling, and carbon fixation by Salicornia brachiata Roxb.: A promising halophyte for coastal saline soil rehabilitation. Int. J. Phytoremediat. 2016, 18, 801-811.

40. Hachiya, T.; Sakakibara, H. Interactions between nitrate and ammonium in their uptake, allocation, assimilation, and signaling in plants. J. Exp. Bot. 2017, 68, 2501-2512. [CrossRef]

41. Kadlec, R.H.; Wallace, S. Treatment Wetlands; CRC Press (Lewis Publishers): Boca Raton, FL, USA, 2008; pp. $257-347$.

42. Margesin, R.; Schinner, F. Potential of halotolerant and halophilic microorganisms for biotechnology. Extremophiles 2001, 5, 73-83. [CrossRef]

43. Tanner, C.C.; Kadlec, R.H.; Gibbs, M.M.; Sukias, J.P.S.; Nguyen, M.L. Nitrogen processing gradients in subsurface-flow treatment wetlands-influence of wastewater characteristics. Ecol. Eng. 2002, 18, 499-520. [CrossRef] 
44. Ventura, Y.; Wuddineh, W.A.; Myrzabayeva, M.; Alikulov, Z.; Khozin-Goldberg, L.; Shpigel, M. Effect of seawater concentration on the productivity and nutritional value of annual Salicornia and Perennial Sarcocomia halophytes as leafy vegetable crops. Sci. Hortic. 2011, 128, 189-196. [CrossRef]

45. Raab, T.; Terry, N. Nitrogen source regulation of growth and photosynthese in Beta vulgaris L. Plant. Physiol. 1994, 10, 1159-1166. [CrossRef] [PubMed]

Publisher's Note: MDPI stays neutral with regard to jurisdictional claims in published maps and institutional affiliations.

(C) 2020 by the authors. Licensee MDPI, Basel, Switzerland. This article is an open access article distributed under the terms and conditions of the Creative Commons Attribution (CC BY) license (http://creativecommons.org/licenses/by/4.0/). 